\title{
PERAN ADMINISTRASI SUPERVISI PENDIDIKAN
}

\author{
DALAM MENERAPKAN MUTU
}

PENDIDKAN KARAKTER DI SEKOLAH

\author{
Rani Novita Sari \\ E-mail : Novitarani@gmail.com
}

\begin{abstract}
Abstrak
Pendidikan diartikan sebagai usaha sadar yang dilakukan oleh pendidik melalui bimbingan, pengajaran dan latihan untuk membantu peserta didik mengalami proses diri ke arah tercapai Dengan demikian, diharapkan pendidik dapat melakukan bimbingan serta pengajaran pada peserta didik hingga pada akhirnya peserta didik menjadi pribadi yang dewasa. Guru selain bertugas untuk mengajar yang secara umum didefinisikan menyampaikan materi pelajaran kepada siswa, guru juga dituntut untuk mampu mendidik siswa menjadi pribadi yang memiliki akhlak mulia. Berbakti kepada orang tua, guru, maupun mengabdikan diri untuk masyarakat. Pendidikan berasal dari kata dasar didik yang artinya memelihara dan member latihan, ajaran, bimbingan mengenai akhlak dan kecerdasan pikiran. (KBBI:2009)

Sarana dan prasarana juga merupakan sesuatu yang penting dalam pendidikan yang merupakan juga hal yang sangat menunjang atas tercapainya suatu tujuan dari pendidikan, sebagai seorang personal pendidikan kita dituntut untuk menguasi dan memahami administrasi sarana dan prasarana, untuk meningkatkan daya kerja yang efektif dan efisien serta mampu menghargai etika kerja sesama personal pendidikan, sehingga akan tercipta keserasian, kenyamanan yang dapat menimbulkan kebanggaan dan rasa memiliki baik dari warga sekolah maupun warga masyarakat sekitarnya. Lingkungan pendidikan akan bersifat positif atau negatif itu tergantung pada pemeliharaan administrasi sarana dan prasarana itu sendiri.

Mengenai karakter Jika kita lihat kondisi pendidikan di indonesia pada saat ini mengalami banyak problematika, bisa kita amati dan temui dalam sehari- hari masih banyak pelajar yang masih kurang dalam hal tata krama ,sikap dan kelakuan. Dalam hal ini sangat diperlukan peran orangtua,guru dan linkungan sekitar dalam membetuk karakter siswa. Seperti yang sudah diterapkan oleh pemerintah yang lebih mementingkan pendidikan karakter kepada siswa.
\end{abstract}

Kata Kunci :Pendidikan,karakter, sarana dan prasarana 
Dalam hal pendidikan di indonesia yang menjadi perhatian kita adalah karakter dan pengetahuan dari siswa tersebut, untuk penerapan karakter pemerintah sendiri sudah menerapkan dalam kurikulum 2013 yang lebih mementingkan karakter. Dalam hal ini perlunya peran dan dukungan orangtua dan lingkungan sekitar dalam membantu membimbing karakter siswa disekolah dan dilingkungan luar sekolah. Pendidikan merupakan salah satu faktor penting kewibawaan sebuah negara didapatkan. Dengan pendidikan yang baik pastinya akan melahirkan generasi penerus bangsa yang cerdas dan kompeten dalam bidangnya. Sehingga kondisi bangsa akan terus mengalami perbaikan dengan adanya para penerus generasi bangsa yang mumpuni dalam berbagai ilmu.

Pendidikan adalah suatu hak dan kewajiban yang harus dilaksanakan setiap manusia. Dari pendidikan seseorang akan belajar menjadi seorang yang berkarakter dan mempunyai ilmu pendidikan dan sosial yang tinggi.Penyebab rendahnya mutu pendidikan di Indonesia antara lain adalah masalah efektivitas, efisiensi dan standarisasi pengajaran. Hal tersebut masih menjadi masalah pendidikan di Indonesia pada umumnya. Selain kurang kreatifnya para pendidik dalam membimbing siswa, kurikulum yang sentralistik membuat potret pendidikan semakin buram. Kurikulum hanya didasarkan pada pengetahuan pemerintah tanpa memperhatikan kebutuhan masyarakat.

Pendidikan tidak mampu menghasilkan lulusan yang kreatif. Kurikulum dibuat di Jakarta dan tidak memperhatikan kondisi di masyarakat bawah atau di daerah sampai daerah terpencil sana.

Sehingga para lulusan hanya pintar cari kerja dan tidak bisa menciptakan lapangan kerja sendiri. Padahal lapangan pekerjaan terbatas. Masalah mendasar pendidikan di Indonesia adalah ketidakseimbangan antara belajar yang berpikir (kognitif) dan perilaku belajar yang merasa (afektif). Belajar bukan hanya berpikir tapi melakukan berbagai macam kegiatan seperti mengamati, membandingkan, meragukan, menyukai, semangat dan sebagainya.

Setidaknya ada beberapa permasalahan yang bisa teridentifikasi dalam dunia pendidikan kita, yaitu: rendahnya kualitas sarana fisik, rendahnya kualitas guru, rendahnya kesejahteraan guru, rendahnya prestasi siswa, rendahnya kesempatan pemerataan pendidikan, rendahnya relevansi pendidikan dengan kebutuhan, dan mahalnya biaya pendidikan.

Berdasarkan uraian diatas rumusan masalah yang kita temui yaitu (1) Bagaimana menerapkan pendidikan karakter kepada siswa melalui supervisi pendidikan (2) Bagaimana Kondisi pendidikan saat ini di indonesia ditinjau dari sarana dan prasarana pendidikan. Dari masalah tersebut tujuan dari tulisan ini adalah untuk mengetahui cara penerapan dari pendidikan karakter kepada siswa dan kondisi pendidikan melalui sarana dan prasarana. 


\section{PEMBAHASAN}

\section{Kondisi pendidikan yang seharusnya terjadi}

Masalah pedidikan, perhatian pemerintah kita masih terasa sangat minim. Gambaran ini tercermin dari beragamnya masalah pendidikan yang makin rumit. Kualitas siswa masih rendah, pengajar kurang profesional, biaya pendidikan yang mahal, bahkan aturan UU pendidikan kacau. Dampak dari pendidikan yang buruk itu, negeri kita kedepannya makin terpuruk.

Pendidikan karakter di sekolah selama ini belum maksimal. Seperti kita melihat tindakan kurang pantas bahkan amoral yang ditunjukkan pelajar kita. Bahkan ada cap generasi muda saat ini telah meninggalkan budaya adat ketimuran.

Pembangunan pendidikan yang sudah dilaksanakan sejak Indonesia merdeka telah memberikan hasil yang cukup mengagumkan sehingga secara umum kualitas sumberdaya manusia Indonesia jauh lebih baik. Namun dibandingkan dengan negara-negara ASEAN, kita masih ketinggallan jauh, oleh karena itu, upaya yang lebih aktif perlu ditingkatkan agar bangsa kita tidak menjadi tamu terasing di Negri sendiri terutama karena terjajah oleh budaya asing dan terpaksa menari diatas irama gendang irang lain. Upaya untuk membangun sumber daya manusia yang berdaya saing tinggi, berwawasan iptek, serta bermoral dan berbudaya bukanlah suatu pekerjaan yang relatif ringan. Hal ini di sebabkan dunia pendidikan kita masih menghadapi berbagai masalah internal yang cukup mendasar dan bersifat kompleks. Sistem pendidikan menjadi bagian tak terpisahkan dari kehidupan sosial budaya dan masyarakat sebagai supra sistem. Pembanguana sistem pendidikan tidak mempunyai arti apa-apa jika tidak singkron dengan pembanguanan nasional.

\section{Bagaimana menerapkan pendidikan karakter kepada siswa melalui supervisi pendidikan}

Pendidikan karakter adalah suatu sistem penanaman nilai-nilai karakter kepada warga sekolah yang meliputi komponen pengetahuan, kesadaran atau kemauan, dan tindakan untuk melaksanakan nilai-nilai tersebut, baik terhadap Tuhan Yang Maha Esa, diri sendiri, sesama, lingkungan, maupun kebangsaan sehingga menjadi manusia insan kamil. Dalam pendidikan karakter di sekolah, semua komponen harus dilibatkan, termasuk komponen-komponen pendidikan itu sendiri, yaitu isi kurikulum, proses pembelajaran dan penilaian, kualitas hubungan, penanganan atau pengelolaan mata pelajaran, pengelolaan sekolah, pelaksanaan aktivitas atau kegiatan ko-kurikuler, pemberdayaan sarana prasarana, pembiayaan, dan ethos kerja seluruh warga dan lingkungan sekolah.

Kegiatan ekstra kurikuler yang selama ini diselenggarakan sekolah merupakan salah satu media yang potensial untuk pembinaan karakter dan peningkatan mutu akademik peserta didik. Kegiatan Ekstra Kurikuler merupakan kegiatan pendidikan di luar mata pelajaran untuk membantu pengembangan peserta didik sesuai dengan kebutuhan, potensi, bakat, dan minat mereka melalui kegiatan yang secara khusus diselenggarakan oleh pendidik dan atau tenaga kependidikan yang berkemampuan dan berkewenangan di sekolah. Melalui kegiatan ekstra 
kurikuler diharapkan dapat mengembangkan kemampuan dan rasa tanggung jawab sosial, serta potensi dan prestasi peserta didik.

\section{PENUTUP}

\section{Kesimpulan}

Dari uraian pembahasan diatas maka dapat kita simpulkan bahwa pendidikan karakter memang sangat diperlukan di Indonesia tidak hanya pengetahuan namun sikap dan tata krama sangat diperlukan kedapannya. Karena dalam mendidik tidak hanya soal pengetahuan namun juga mengenai pentingnya karakter. Pendidikan karakter dapat diintegrasikan dalam pembelajaran pada setiap mata pelajaran. Materi pembelajaran yang berkaitan dengan norma atau nilai-nilai pada setiap mata pelajaran perlu dikembangkan, dieksplisitkan, dikaitkan dengan konteks kehidupan sehari-hari. Dengan demikian, pembelajaran nilai-nilai karakter tidak hanya pada tataran kognitif, tetapi menyentuh pada internalisasi, dan pengamalan nyata dalam kehidupan peserta didik sehari-hari di masyarakat.

\section{Saran}

Pentingnya supervisi bagi sekolah agar sekolah dapat memanage segala sesuatu yang berhubungan dengan proses terjadinya pendidikan dalam sekolah sehingga cita-cita dan tujuan dapat tercapai dan terlaksana dengan baik.

\section{REFERENSI}

http://ejournal.unp.ac.id/index.php/pedagogi/article/view/4275 